\title{
The Urban Theme in Recent Soviet Russian Prose: Notes Toward a Typology
}

Late in Doctor Zhivago, after its lyrical nature descriptions and idyllic back-tothe-earth retreats in rural Varykino, we run into the following startling passage:

These notes were found later among his [Zhivago's] papers: "When I came back to Moscow in 1922 I found it deserted and half destroyed. So it has come out of the ordeals of the first years after the revolution: so it remains to this day. Its population has decreased, no new houses are being built, and the old ones are left in disrepair.

But even in this condition it is still a big modern [sovremennyi] city, and cities are the only source of inspiration for a new, truly modern art.

The seemingly incongruous and arbitrary jumble of things and ideas in the work of the Symbolists (Blok, Verhaeren, Whitman) is not a stylistic caprice. This is a new order of impressions taken directly from life. Just as they hurry their succession of images through the lines of their poems, so the street in a busy town hurries past us, with its crowds and its carriages at the end of the last century, or its streetcars and subways at the beginning of ours. Pastoral simplicity does not exist in these conditions. Its pseudoartlessness is a literary fraud, an unnatural mannerism, a bookish phenomenon, not inspired by the countryside but taken from the shelves of academic archives. The living language of our time, born spontaneously and naturally in accord with its spirit, is the language of urbanism. . . The city, incessantly moving and roaring outside our doors and windows, is an immense introduction to the life of each of us."1

What are we to make of Pasternak's contention in view of the current Russian infatuation with derevenskaia proza (rural prose)? Was he just plain wrong about what the main theme, inspiration, and form of the literature in his own time was (he died in 1960), or did intellectual and imaginative developments in Soviet Russia veer off in a sharply different direction after his death?

In the last fifteen years, an ocean of Russian literary vitality has indeed poured itself not only into novels and stories, but also into poems, films, and dramas about Russian villages, the countryside, and folksy rural characters of the kind that we associate, to begin alphabetically, with Abramov, Astaf'ev, Belov, and on through the time-hallowed name of Rasputin to the more recently

1. Translation slightly altered by George Gibian from that by Max Hayward and Manya Harari, Boris Pasternak, Doctor Zhivago (New York: Signet Books, 1958), pp. 406-7 (Russian original, University of Michigan edition, 1958 [?], p. 500). This was not a freak, isolated statement by Pasternak. In his autobiography he made a similar remark, not in Zhivago's name, but in his own: "How that style [Blok's] seemed to agree with the spirit of the age ... the language of conspirators of which the chief character was the city and the chief event the street" (Boris Pasternak, I Remember [New York, 1959], p. 50). The Zhivago poem "The Earth," the late poems "Na rannikh poezdakh" (1941) and "V bol'nitse" (1957), and others also speak of the urban theme in similar language. 
worshipped Shukshin. This national passion amounts to something which must be explained as much by social psychologists or anthropologists as by literary historians and critics, for it is attributable to an extraordinary receptivity to patriotic appeals and to a thirst for a return to national roots, childhood, and the past, not only among intellectuals in Soviet Russia's large cities (for they are the main consumers of this cultural product), but also among émigrés in Paris and New York. Yet it is my thesis that Pasternak was not mistaken in his statements about the city as the theme for Russian writing in his and our age. Derevenskaia proza is one symptom of a resurgence of a special kind of Russian nationalism and one embodiment of an old pre-Soviet Russian national literary tradition, but it is not the only such present-day reincarnation. The city also continues to be an important theme and inspiration, ${ }^{2}$ and in the long run may be found to have been more conducive to complex artistic statements and, paradoxical though this may sound, to have been as much of a national (narodnyi) Russian art form as the derevenshchiki. Soviet literature today can be understood best through an awareness of the dialectical relationship between rural and urban thematics.

The urban element is not just a setting, but plays an important role connected with, and influential in relation to, other features (theme, characters, plots). When we attempt to group urban prose of the last decades according to the dominant views and uses made of the city, we find that it is possible to distinguish five main categories, each of which, because of the need to be selective, will be illustrated by no more than three representative authors, and most of them by only one.

The volume of Soviet literature is massive; one's time (and dedication and eyesight) is limited. With the best will in the world, one can read only a small fraction of what is being published. Hence one must be modest in making claims about the groupings of chief themes which one believes one has distinguished in Soviet prose as a whole. The five classes below are not being offered, dogmatically, as indisputable, cleanly separate categories, but as tentative suggestions, to serve as bases for a discussion of thematic emphases in Russian urban prose today.

\section{The City as Octopus}

Our exemplary work will be Natal'ia Baranskaia's $A$ Week Like Any Other (Nedelia kak nedelia) (Novyi mir, 1969, no. 11).

The heroine of this story, Olga Nikolaevna, is a "junior research assistant," hence professionally an enviably situated member of the intelligentsia, one who has made it. The city of Moscow is the locale of her scientific employment-some kind of vitreous plastic research institute-and the place where the quality of her life is determined. The dominant urban spirit is that of hurry and of a variety of tensions enveloping her with tentacular pressures.

She is entrapped and pursued by the specters of norm fulfillments, requirements, deadlines. This is the world which Soviet journalists routinely describe

2. Iurii Nagibin's sketch, "So Much of Moscow in That Sound" ["Moskva tak mnogo v etom zvuke"], Novyi mir, 1976, no. 11, deals with the city of Moscow but displays the same emotions of nostalgia for what is old, unspoiled, and natively Russian as Soloukhin and other authors of village prose show in writing about the countryside. 
as that of NTR-nauchno-tekhnicheskaia revoliutsiia (scientific-technological revolution) or, as we should perhaps put it, the modern technological society. Her life is ruled, within this large urban world, by one small ticking object, the alarm clock. She never has enough time or sleep.

The pressures and demands surrounding her include her husband, whoalthough their marriage is a model one, and they are both fond of and even in love with each other-is unreliable and recalcitrant when asked to do what is considered woman's work-minding the children and cooking for them.

At Olga's institute, a demographer is passing around questionnaires with such items as why staff members did or did not have children, asking them to classify their motives under stilted rubrics, and using generalizations, groupings, and stereotypes which do violence to the spontaneity, emotionality, and complexity of real life. The heroine's actual existence consists of chasing buses, tripping while getting into them, being late for work, missing seventy-eight days of work a year because of children's sicknesses (almost a quarter of a year, her husband remarks), forgetting to turn on the alarm clock or forgetting that she had a seminar to go to and therefore annoying her husband through her unexpected lateness in getting home. Unpleasant surprises typical of her way of life in this quite typical week include an above-normal work request to the laboratory; but the crux of it all is lack of time and the concomitants-the need always to hurry and the lack of sleep. Commuting (by bus, subway, and trolley bus), the questionnaire elicits, takes about three hours a day. It is clear that the questionnaire also serves the useful literary function of bringing out statistical facts of this urban life. Only 48 to 53 hours a week, an addition shows, remain for home.

The artificial, abstract world of the questionnaire is disrupted by manifestations of harassed humanity-her child is violently ill; Olga has hysterics. She does an impromptu skit parodying an answer to the questionnaire. She mocks the question about motivation for having children: "Comrades! Let a mother of many years' standing have the floor! I assure you that I bore my children exclusively for civic considerations. I challenge all of you to competition and hope you will beat me in quantity as well as in quality of production."

The manner in which she actually decided against an abortion and for having her second child-an emotional, illogical conversation with her husband which she recalls-contrasts with the official phraseology of a colleague, Maria Matveevna: "A Soviet woman will guide herself by public, national interests in such a matter as bearing children." Maria's clichés sound vapid alongside vivid accounts of children having diarrhea, family arguments, and group shopping during lunch breaks.

The story is partly in the vein of Soviet documentary prose. The plot is minimal. The week of the story, divided by subheadings, day by day, Monday through Sunday, presents the routine of hourly and weekly life-the grind and pressure. It is as close as one can get to reportage, and is in this regard representative of that huge very popular category of semifictional, semijournalistic short prose in Russia today, so reminiscent of our own "New Journalists" (for example, Tom Wolfe). (Soloukhin, Granin, Bitov, and many others have made excursions into this genre.) It is not an attempt to write a new gospel (which Sinyavsky said is the main endeavor of most of Russian literature) or to show the road to salvation. It concentrates on the here and now-on description 
of things as they are, reality, the concrete particular contrasted with the debased, institutionalized phraseology of the questionnaire. It is neither prophetic vision, nor sermon; it is not nationalistic, but it is national, Russian. It belongs to its place and its time, and concentrates on presenting a view of how life is in the octopus-like embrace of the metropolis, in the tradition of Grigorovich and Nekrasov, with modern modifications in tone.

The urban presence in Baranskaia's story, then, is felt as one which tends to overwhelm the chief character. It is necessary to struggle against it in order to be able to draw a free breath (literally, in the sense of holding on to some time in which to do what one wants; and, metaphorically, of preserving some genuine individuality against the falsifying, dehumanizing violence being done to life by the formulas of the anketa). The two inimical forces are linked by being the two faces of the urban milieu.

Olga's dilemma could well be summed up as self-defense against the twin perils, the anketa and the alarm clock, with all the broad implications of the two small material objects. The specifics of her struggle are unique to this particular story, but the vision of the city as an octopus emerges in other Soviet works, if not pervasively, as in Baranskaia, then at least in some parts of them. Iurii Trifonov's House on the Embankment (Dom na naberezhnoi) (Druzhba narodov, 1976, no. 1), for example, presents successive stages, from the 1930s till the "Thaw," of oppression and falsehood concentrated in the Moscow "house with the thousand windows" where the powerful predators reside, whereas the humble courtyards shelter a more elemental life of the populace. (We should also remember that literature of Western countries presents similar views of the modern metropolis. ${ }^{3}$ )

\section{The City of White Nights, Dreamers, and Seekers}

A situation peculiarly appealing to twentieth-century man is that of the young person "trying to find himself." The vague and trite phrase "finding oneself," so frustratingly familiar to us today, can mean finding a vocation (literally a profession or a job) or discovering what one values in life, what one wants to look for, or it may mean finding some basic truth-a philosophy of life. It is always a quest for a discovery connected with the self.

This search is as old as Oedipus and Aeneas, or Pierre Bezukhov and Konstantin Levin. One contemporary Soviet Russian model is almost identical with what is called molodaia proza, prose of youth. Vasilii Aksenov has been the chief author in this category, but he has many fellows. ${ }^{4}$ There are several variants in approach to, and orientation of, the quest, and even more in the texture and dominant literary qualities of the stories. Abramov, Belov, and Shukshin are also often preoccupied with a young man's quest for his calling

3. See, for example, Marilyn S. Fries, "The Significance of Spatial Constructs in the Literature of the City," in The City and Sense of Community, ed. Sander L. Gilman (Ithaca, N.Y.: Center for Urban Development, Cornell University, 1976); and Otto Friedrich Bollnow, Mensch und Raum (Stuttgart, 1971).

4. On the first introductory page of Kollegi (1961), Aksenov states with defiant bluntness what the dominant situation will be in that book. The remark applies to many others: "This is a tale about young colleagues-doctors, seeking their place in life and finding it, a tale about the young generation, about its thoughts, feelings, love." 
but they look back to the village prose of Grigorovich, ${ }^{5}$ of Turgenev's Hunter's Sketches, of Bunin and Prishvin. Aksenov, Bitov, and Gladilin, on the other hand, derive from Dostoevsky's urban stories of the dreamer (mechtatel') and of Petersburg's White Nights. But just as there were foreign, perhaps distracting, parallel influences in the 1840s (George Sand's La Mare au diable and La Petite Fadette for Turgenev; Balzac for Dostoevsky), so is Salinger an analogue (parallel, not source, since Aksenov wrote his basic stories before he became acquainted with the simultaneously published first Russian translations of Salinger) in the middle of the twentieth century. ${ }^{6}$

An important characteristic of the Aksenov-Gladilin school is the flippancy and cleverness of the heroes' language. They are suave, slick, cool, intelligent, educated, ironic. In their sophistication and disillusionment, they contrast sharply with the generation of their fathers. In Gladilin's little masterpiece "First Day of the New Year."7 the heart of the story lies in the contrast between the son (at a point of crisis in his life) and the father (dying of cancer in a hospital) and in the effort at communication across a huge gap-speaking haltingly in two different languages, from two different sides of the barricades, albeit the issues are the same ones.

Aksenov's short stories and novelettes (Colleagues [1960], Starry Ticket [1961], Oranges from Morocco [1963]) established this subgenre; it ran its course rather quickly. The stories seemed novel and fascinating, and to some readers, even sensational, but they have not aged or traveled well. Aksenov's heroes sometimes work out their finding of themselves in remote places-Siberia, or islands, towns, and beaches of the Baltic - but they are urban dwellers, formed by the big city, imbued with its sophisticated, confusing, value-destroying milieu. The city is where the action is, even if, as in the short story "Half Way to the Moon," the hero is a truckdriver who only gets a whiff of cosmopolitan and metropolitan culture, at a distance, from the airport and on board an airliner, shuttling between eastern Siberia and Moscow.

In Aksenov's melancholy "Dad, Spell It" ("Papa slozhi" [1962]), the ex-soccer player finds he is getting old, his wife may be deceiving him, she and he belong to different educational categories, a phase of his life is ending, the future is uncertain. He takes his little daughter from café to café, broods about his life, and roams the streets of Moscow much as Raskolnikov had in Petersburg. The labyrinth of the city surrounds him as he walks through it, a setting for his semiarticulate, semiemotional responses, evoking in him ruminations about the stages of his life. His is a Moscow of football stadium crowds. On the last page, Aksenov gives a panorama of the city, seen through the sadder, possibly wiser, hero's eyes and ears:

5. Turgenev called Grigorovich's Village (Derevnia, 1848) the first attempt "at bringing our literature close to national (narodnaia) life" (quoted in A. Ninov, Sovremennyi rasskaz [Leningrad, 1969], p. 25).

6. In a questionnaire in Voprosy literatury, Aksenov answered the question "Which traditions in classical and contemporary literature are close to you?": "The traditions of Russian classical literature, the traditions of Tolstoy and Chekhov. Soviet literature of the twenties and early thirties interests me enormously. Reading Babel' and Andrei Platonovthat is a good school. Hemingway, Faulkner, Böll, Salinger-that is also a first-class school, besides the pleasure which the reading of their books gives one." 1965 ).

7. Iunost', 1963, no. 2, pp. 31-57; and in book form, Pervyi den' novogo goda (Moscow, 
Further on was the park, the rows of trees, and Moscow, Moscow, impossible to see all of it, burning with millions of sunlit windows. There in Moscow is his house, 35 square meters, there, in Moscow, there are telephone booths on all street corners, in each of them one can find out about danger, in each of which the heart can skip and legs buckle, in each of which finally one can calm down. There in Moscow all his 32 years are quietly walking out on the streets, calling out to one another, and not finding one another. There in Moscow are many pretty girls, hundreds of thousands of pretty girls. There wise institutes carry on research, there people are being promoted. There are his calmness and his worries, his puppy love which has come to an end. There is his youth which passed like a cheerful, incredibly tall schoolboy, in its training halls and stadium, in gangs and beer halls, in dance halls, in underpasses, in kisses, in music in the park. . . . There is everything which will yet come to pass with him. And what's to come later? Who knows. [Chto potom? Sup s kotom.] ${ }^{8}$

The city is his entire life, an all-encompassing medium; it evokes in him thoughts and reminiscences. The city is both the setting and the stimulus for dreaming, wandering, and wondering.

The urban world of Gladilin's Forecast for Tomorrow is very similar to Aksenov's -a medium which evokes lyricism:

The city-thousands of faces, thousands of faces which we see in the subway, in the trolley bus, on the street. Among these thousands, we know ten, at the most a hundred. We smile at them unwittingly, or on the contrary turn away, or in vain try to remember where we met that man. . . . We are crammed into subway cars, we must ride a long twenty minutes, we are in a loathsome mood, and in front of us again there are faces of people, faces which are probably very beautiful, but which now seem caricatures to us-we don't know which way to turn, we simply have no place to go. We close our eyes or get out an old newspaper, again read about American imperialists and Israeli aggressors and Bonn revanchists, news we already heard in the morning on the radio. There is no newspaper and we again look with envy at the lucky ones who are sitting down, buried in books, at the owners of the latest evening paper-youth has passed [Gladilin breaks in without transition-abruptly-as though it followed from what he has been narrating], when every minute we dreamed of an accidental meeting, about how the door will open and she, the beautiful unknown one, will come in. The time passed when for every man we tried to guess his character, profession, family situation. Alas, every day we spend three hours commuting and so many years make up an uninterrupted subway-thousands of cars, millions of faces. . . Y You get out (sighing with relief) at your stop. ${ }^{9}$

The city here connotes the subway and masses of people. It is a reminder of change, of the passage of time, felt as a loss of the past.

The hero and narrator of the story has two major decisions to make-about his profession and a choice between his mistress and his wife. Both turn out to be connected with a third problem-his relation toward the many or the 
few-because the argument for devoting himself to his scientific career (and to his mistress) is that he owes it to millions of people now and in the future to fulfill his utmost potentialities in scientific research. An appeal is made to him to choose work (plus mistress) and to downgrade the importance of his wife and daughter. ("Problems of your family are problems of millions of people in all countries. Every minute on earth thousands of people are born and die. They are not able to do what you can. The world is huge. Billions of new people will appear, but you will not be here any more. You will have died and not fulfilled your destiny.") He rejects the "abstract man" for whom he may be thought to be predestined. He decides that "even if I really . . . am of some kind of value to millions of people, so for me these millions begin with my two girls [his wife and daughter], they can't live without me and I can't live without them, and if my two girls are not there, then I don't give a damn for those millions, without them [the two girls] I have nobody, nobody needs me."10

$\mathrm{He}$ chooses the smallest concentric circle-those nearest to him: intimate, immediate personal relations; closeness, rather than anonymous, vast, remote links to millions and to the future. The city, which to him represented scientific possibilities, as well as gangs of young boys and girls, is the arena of his basic decision making, centered on the problem of which human links, those with the many or those with the ones closest to him, he should give preference to. $\mathrm{He}$ had been a weather station technician in the far north, and a fisherman in the far east ("Looking for the Fire Bird"), but it is the city where the two crucial decisions come to a head and are solved by him.

Andrei Bitov's stories often present heroes who are modern versions of Dostoevsky's Underground Man crossed with his dreamer. Many of them are children or adolescents. In "The Door" ("Dver"'), the young man spends most of the night outside of an apartment where his girl is visiting, consumed by pangs of jealousy, imagining who she may be with, and picturing what terrible things he will do to her when she comes out of the apartment. (When she does come, he accepts her explanation with amazing alacrity.) Most of the story consists of an unhappy stream of consciousness of the upset young man's imaginings.

Another hero daydreams while traveling through the city on a streetcar. Reverie was Bitov's dominant mode in his early stories, the hero's mind wandering while, for example, he is being reprimanded by his boss. In an unpublished story (written in 1963), "Notes from the Corner" ("Zapiski iz-za ugla") he wrote, "Depiction of the falling asleep of consciousness, the replacement of consciousness by a reflex, the life of the intellectual without intellect, is, it seems to me, so characteristic of our time. All this has been pursuing me as a theme for such a long time, as can be seen in 'Penelope,' in 'Garden' ('Sad'), and in 'Life in Windy Weather." "11 The protagonist of "The Loafer" ("Bezdel'nik") daydreams on a bus, imagines he sees a woman murdered, goes to a movie, wanders about, just as when he was in school and played hooky. (Bitov's city dwellers, when not children, often act as if they were still children. His stories in the early sixties are usually seen from the point of view of a child, whereas Semin's are those of a grownup and Trifonov's of an old person looking backward.) We are not surprised that the "loafer's" boss needs to remind him,

10. Ibid., p. 186.

11. Manuscripts in the possession of George Gibian. 
"You are a grown-up man, Vitia." His consciousness wanders off the main thing, on to irrelevant side issues-for example, a cactus on a window sill. The center dissolves into an urban panorama (a red streetcar with a white roof, the blue cupola, black-white trees, the church, the square, in "Bezdel'nik"). The peripheral issues, which include the cityscape, are the main thing for the character.

The dominant medium of refracting and absorbing the small incidents (often even imagined nonincidents, as in the static wait in the doorway in "The Door") in Bitov is sensibility: moody, receptive, hypersensitive. The episodes carry the message of insignificance. Things do not come off. A brief encounter with a girl leads to nothing-connections are broken off, falsely stated, misleading. In "Wife Not At Home," his hero makes a date with a girl which he does not really want to keep; he then comes too late and she is gone. He goes to a movie which he does not want to see; he gets there late also. The characters are aimless people, bumming around town, drinking, feeling, dreaming.

Bitov's stories in the early $1960 \mathrm{~s}$, it must be said, were only a stage. They were succeeded by new themes, new narratives-so different one might not guess that the same author had written them. Subjective lyrical dreaminess was replaced by objectivity, adolescent sensitivity by reportage, reverie by objective documentary prose. ${ }^{12}$ It was in his earlier works that Bitov was a twentieth-century follower of Dostoevsky's theme of city-inspired dreamers and sensitive young people.

In this large category of prose works, the city functions as the stimulus to, and setting of, self-analyses and reveries. Youthful, confused heroes wander in an urban setting reminiscent of the Petersburg of young Dostoevsky (although in Soviet Russia today, Moscow most of the time replaces the former capital). The city is a catalyst in the characters' working through their lyrical introspections.

\section{The City as a Big Village}

An entirely different view of city life is taken by Vitalii Semin. His characters often live in smaller towns (he himself is from Rostov), or they live at the edge of a town. Their ways are old-fashioned and rural. They are villagers who have moved into industrial life, but their attitudes, emotions, traditions are those of Russian peasants. Their language is quaint, colorful, full of proverbs. The center of their lives is the family-and its physical envelope, the house. One might say that the city for Semin's characters is a metamorphosed village, and that it is all telescoped, shrunk into a house. The typical activities of his characters are building a house for oneself or helping someone else in the cooperative

12. Bitov wrote a meditative travelogue, Journey to Armenia (Puteshesivie v Armeniiu), and The Wheel (Koleso), a "New Journalism," Tom Wolfe-like account of the world's capital of motorcycle racing on frozen lakes, Ufa. Perhaps most important of all, he also wrote a long, complex, sophisticated novel about three generations of people, with a hero who is also a literary scholar, Pushkinskii dom. This book is hitherto unpublished; only a few fragments have been printed. Those who have read the manuscript report that it is a very literary, self-conscious work, reminiscent of Nabokov's Dar', compounded of many genres and couched in a variety of narrative techniques. Until we can read it and consider it carefully, we cannot make any judgment about its qualities-or its urban themes. In this complex work, it seems that not space, but time is the subject. 
enterprise of building a house; worrying about the troubles in someone's immediate surroundings (a relative or quasi-relative), but without bothering about morality or broader social contexts, since one helps even a thief and murderer if he is of one's own milieu; drinking ; eating; arguing; and telling stories.

The women are the heroines: they hold the house together-and that is the center of all life. Semin's Seven in One House (Semero v odnom dome) (Novyi mir, 1965, no. 5) ought to be regarded as the complement to, or that which completes our understanding of, Solzhenitsyn's "Matryona's Farm" ("Matrenin dvor") -which I consider the masterpiece of the entire school of derevenskaia proza, although, of course, we cannot expect anyone in Soviet print to admit this central fact. Seven in One House, like "Matryona's Farm," is also hagiography - the heroine and saint, Mulia, however, is urban, not rural, and active, self-assertive, rather than religiously contemplative and passive as is Matryona.

Semin's characters, simple people, with their curse words and proverbs, truly folksy, have one chief quality-vitality. They are traditional, as close to the soil as anybody in Russian literature, but they have moved these qualities of outlook and speech away from the soil, and they have brought them along into the houses they are building for themselves, near where the factories are in which they earn their livings.

There is seldom much plot in Semin. His works are an apotheosis of byt (the folkways and material details of everyday life), as well as of the strength of the Russian nation-primarily of female vitality. Thus Mulia "would not share power with any man ... in our house." The amorality and uncivicmindedness which Soviet critics have deplored in Semin are really a glorification of small town resilience. "She lived in this world. Neither better nor worse than others," sums it up. Hard work and endurance are other traditional Russian qualities which these urban dwellers display. These people seem to come not just from a different country but from a different planet than Bitov's dreamers and Gladilin's educated youngsters. They admire practical handyman-type expertise, and matter-of-factly practice age-old customs (such as pouring out vodka so that their house will not smell badly for a thousand years).

Semin is not interested in intellection. He studies the details of male-female relations, and his plots are rich in situations that parallel the Russian proverbs which orient his characters' attitudes (for example, that it is when food is on the table, and especially wine, that reconciliations take place within families) and which permeate their language. The women are strong not only in keeping power, but also in their love and loyalty. ("Asia Aleksandrovna," another story by Semin, is told from the point of view of a man who only when his father is dying comes to know and admire his stepmother, who had "always fought for father, and against me, against the neighbors, against doctors, against my mother, whom my father divorced five years ago, and now she fights against the emergency doctors who came late and did things wrong." ${ }^{18}$ It is her strength, constancy in love, and loyal combativeness which arouse his admiration.)

Semin writes of people from the soil, who fashion their cities, houses, habits, and speech into images of their ancient Russian rural traditions. The Russian towns of this Leskovian writer are dominated by the folkways of women of incredible resilience.

13. V. Semin, "Asia Aleksandrovna," Novyi mir, 1965, no. 11, p. 78. 


\section{The City as Site of Factories and Research Institutes}

To work out the conception of city life as primarily the site of industrial production would mean surveying the entire huge field of production literature (proizvodstvennyi ocherk, povest', rasskaz, roman). Suffice it to say that this is probably numerically the largest category of Soviet writing even in the sixties, although proportionately it has somewhat diminished from its peak in the last years of Stalin's life. Whether straight socialistic realism (Kochetov, Sofronov) or straight "Thaw"-period inversion of it (Ehrenburg's Thaw, Dudintsev's Not by Bread Alone), such works conceived of the struggles within industrial production as tantamount to basic moral problems: the collective versus the individual, with one or the other cast as hero; public and professional life versus private, emotional life (again with one or the other taking precedence). I omit analysis of this category because it has been done before. ${ }^{14}$ To rehearse it once more would be repetitious.

\section{City as Locale of Perennial Ethical Dilemmas}

In discussing Russian urban stories of the 1960s, it is impossible to pass by the long stories of Iurii Trifonov, who has made such a startling rise in seriousness and general quality since his early novel Students (1944). He himself refers to these tales as "city stories" (gorodskie povesti) ${ }^{\mathbf{1 5}}$ : Exchange (Obmen) (1969), Summertime Noon (Byl letnii polden'), Preliminary Results (Predvaritel'nye itogi), and Long Farewell (Dolgoe proshchanie) (Novyi mir, 1971, no. 8). They have in common an immense inventiveness-two or three pages of Trifonov sometimes summarize so many lives, give such compressed accounts of so many events, that they would supply material for several novels by other authors. Trifonov is concerned with intercatenations of family fates; with a middle-class or upper-class intellectual milieu; and with the ugliness of a persistent meshchanstvo (petty bourgeois meanness). He analyzes closely the actions and reactions of people who gradually, before our eyes, and sometimes before their own eyes, are revealed as plotting to have the mother, who is terminally ill with cancer, move in with the family, so that it becomes entitled to a larger apartment, one they will be able to keep even after, as is expected, she will have died. In his latest and most powerful work, The House on the Embankment (Dom na naberezhnoi) (Druzhba narodov, 1976, no. 1), he studies the mechanics of moral cowardice among literary scholars in Stalinist Moscow, especially the details of the processes by which morally neutral men were induced step by step to behave despicably.

Trifonov does not, as so many published Soviet authors do, avoid the real and burning issues of our day, nor does he simplify. On the contrary, he convinces us breathtakingly that he has an intimate knowledge of the small superficial details, the ways of doing and living of Soviet people today, and of the

14. George Gibian, Interval of Freedom: Soviet Literature During the Thaw, 19541957 (Minneapolis: University of Minnesota, 1960), especially chapter 2, "The Scientist as Hero, Saint, and Martyr," and chapter 4, "Versions of a Soviet Inferno." Vera Dunham, In Stalin's Time: Middleclass values in Soriet fiction (Cambridge: Cambridge University Press, 1976), illustrates in great detail this and many other aspects of the sociological documentation discoverable in Soviet literature.

15. Interview in Literaturnaia gazeta, in 1974, with Iurii Trifonov, "Sovremennost'splav istorii i budushchego." 
central moral issues-sins of action and omission-which daily confront Soviet people in the middle and upper reaches of the urban social pyramid. The various forms of bourgeois meanness gradually emerge, and while it may be excessively complimentary to call him today's Soviet Russian Henry James, he does share with the American master a subtle, complex, analytic, socially-oriented moral consciousness.

Like Gladilin, Aksenov, Bitov; Granin, and many others, Trifonov has also written historical works, and his tales of the urban Soviet present are permeated with a sense of the past (as was Henry James). His Russian national identity rests in this living Russian legacy which one feels in his works. To him, city life is where the moral face of Russia today can be read.

There are writers (Iurii Nagibin, Iurii Kazakov, I. Grekova, Daniil Granin, particularly in "Rain in a Strange Town" ["Dozhd' v chuzhom gorode"]), who are interested in showing how emotional life, as we know it from the Russian classics, far from having vanished from the face of the earth, has survived, naturally in modified form, yet as intense as ever. Trifonov pursues the avatars of nineteenth-century Russian literary studies of the dilemmas of morality. $\mathrm{He}$ is one of those Soviet authors who turn to the city scene in order to reveal acute moral dramas in the shape of human responses to a very Soviet, modern, metropolitan setting. These ancient yet contemporary problems are not uniquely Russian, but they are peculiarly Russian.

We often have been warned against identifying Russian nationality (narodnost $t^{\prime}$ ) with birch trees and folk songs. Pushkin wanted narodnost to mean something deeper than merely taking a theme from the national milieu and history-to him it was a way of thinking and feeling, it derived from the customs and superstitions produced by climate, government, faith: "There is a way of thinking and feeling, there is a mass of customs, superstitions, and habits, which belong exclusively to a particular nation."16

When Turgenev praised Dal', in a review of his Povesti, skazki i rasskazy Kazaka Luganskogo (1847), as more than anyone else deserving the title of national writer, he praised not only his sketches of rural Russians, but specifically also of urban occupations: "a fat-bellied merchant," "a janitor" (dvornik), "a civil servant of middle rank." 17 Moreover, not rural elements, but a sympathetic attitude and the ability to observe closely were the main thing to Turgenev. We might add that narodnost', in Russian music as well as in literature, has consisted not only of matters of content, but of formal and structural qualities: of following the Russian conventions of constructing a novel or a short storyand here the examples of Pushkin, Turgenev, Chekhov, and Dostoevsky are clear. Certain ways of conceiving and analyzing a character's mind, avoiding contrived plots and set genres, simplicity of narration, and directness are also some of the Russian national traditions in literature.

The derevenshchiki of the past fifteen years represent an important continuation of some great Russian traditions, especially the one running from Turgenev's Hunter's Sketches through Bunin to Prishvin. The writers of city tales, on the other hand, continue the complex Dostoevsky-Tolstoy-Chekhov line and share with the derevenshchiki their Leskovian heritage.

16. Pushkin-Kritik, ed. N. V. Bogoslavskii (Moscow-Leningrad, 1939), pp. 92-93.

17. Quoted in A. Ninov, Sovremennyi rasskaz, p. 22. 